SHS Web of Conferences 12, 01020 (2014)

DOI: $10.1051 /$ shsconf/ 20141201020

(C) Owned by the authors, published by EDP Sciences, 2014

\title{
Sustainable Mountain Tourism: An Analysis of Bosnia- Herzegovina's Wine Tourism and its Future
}

\author{
John Hudelson ${ }^{1}$ \\ ${ }^{1}$ Global Wine Studies, Central Washington University, Ellensburg, Washington, USA
}

\begin{abstract}
Bosnia-Herzegovina (B-H) remains one of the most underdeveloped countries on the European Continent [1] yet it holds great potential as a tourist destination for outdoor adventurers, history enthusiasts, and now, wine connoisseurs. The southern part of this merged nation has always been an area of wine production, but the industry has been slow to develop into a net exporter of its wines. The author and many of the industry's supporters believe that it would be more lucrative to follow in the footsteps of its western neighbor, Croatia, and develop the wine industry through wine tourism. Utilizing historical data, interviews, analysis of governmental statistics, review of the literature and finally a SWOT analysis, this paper suggests changes and expenditures required for BosniaHerzegovina to become a successful wine tourism destination. It is hoped that the suggestions made herein will direct further discussions if not actions in that direction.
\end{abstract}

\section{Introduction: The History of Wine Making in Bosnia-Herzegovina}

Bosnia-Herzegovina's history of wine making has flourished and waned over the centuries. From the era of the $12^{\text {th }}$ century Byzantine Empire to the Ottoman invasions, its identity as both a wine producer and a state (Banate) thrived. The Turks put an end to commercial wine trade, but a local Slavic-speaking Muslim community emerged that probably continued to make wine, at least at home. With the arrival of the Austro-Hungarian control, vineyard land was expanded, and it remained stable through both pre- and post-World War Two Yugoslavia. It was at the dismemberment of the Socialist Federal Republic of Yugoslavia (SFRY) that the country was nearly decimated by its adjoining neighbors [2]. The return to normalcy has been difficult, but wine once again flows there. This tenacious, war-torn country produces wine mostly for domestic consumption at this time (although, many times more than does England). Bosnia-Herzegovina has for years based its reputation and its industry on two noteworthy grape varieties. It still grows a sexually non-perfect vine called Blatina. Alicante Bouschet (Kambuša), Merlot, or the native Trnjak must be grown with this vine in order to fertilize its female flower. This is always an uncertain situation as the plant blooms during a season of frequent rains. This dark red grape produces wine with rich aromas and flavors that are spice and coffee-driven. Aging of the wine can often result in dry chocolate flavors.

Bosnia-Herzegovina's second outstanding variety is its native white grape Žilavka, which produces wine with a nutty-aroma. It likely is named after the small veins ('žila' means vein) that 
appear under it translucent skin when the fruit ripens [3]. These varieties, along with the red grape Trnjak have helped to put Herzegovina on the wine map. About $55 \%$ of the wine produced is white, with the most of the rest red and only a small portion of Rosé. Bosnia-Herzegovina winemakers differ from those of many Balkan wine industries in that they feel their success will eventually be with the autochthonous varieties or with the Balkan native Vranac, which also grows well in most Herzegovinian soils. While interest in these varieties is growing among wine connoisseurs, the author believes that their growing reputation can be better used as a draw for wine tourism than for just wine export purposes. Examples from similar low wine production countries such as Croatia and Cyprus show a marked increase in profit ratios when comparing money made in wine tourism to money made in wine exports. Whether Bosnia-Herzegovina can successfully follow their example remains an unexplored question. This paper fills this research gap by considering the numerous requirements of wine tourism and applying them to the case of Bosnia-Herzegovina with the objective of determining the likelihood of successful wine tourism there.

\section{Methodology: A Case Study Background of Bosnia-Herzegovina's Wine Industry}

Herzegovina in the south is the one and only wine region of the country. However, two river basinsthe Neretva and Trebišnjica-form the geographical centers of two sub-regions: one based around the town of Trebinje and the other around the towns of Čitluk and Međugorje near Mostar (Fig. 1). Both of these sub-regions are semi-mountainous and continental in climate, and both display Karst limestone soil formations perfect for vinifera grape production.

Under Josip Broz Tito's communism, wine production was quite a bit higher than present, but its quality was lower. After Bosnia-Herzegovina left Yugoslavia, the large cooperative HEPOK-Mostar was split up into five small industrial-scale wineries with a total acreage of 420 hectares. Čitluk, Ljubuški and Stolac are the largest of these and the largest in the nation. However, most of the country's wineries have fewer than 20 hectares (50 acres), making them family-sized farms.

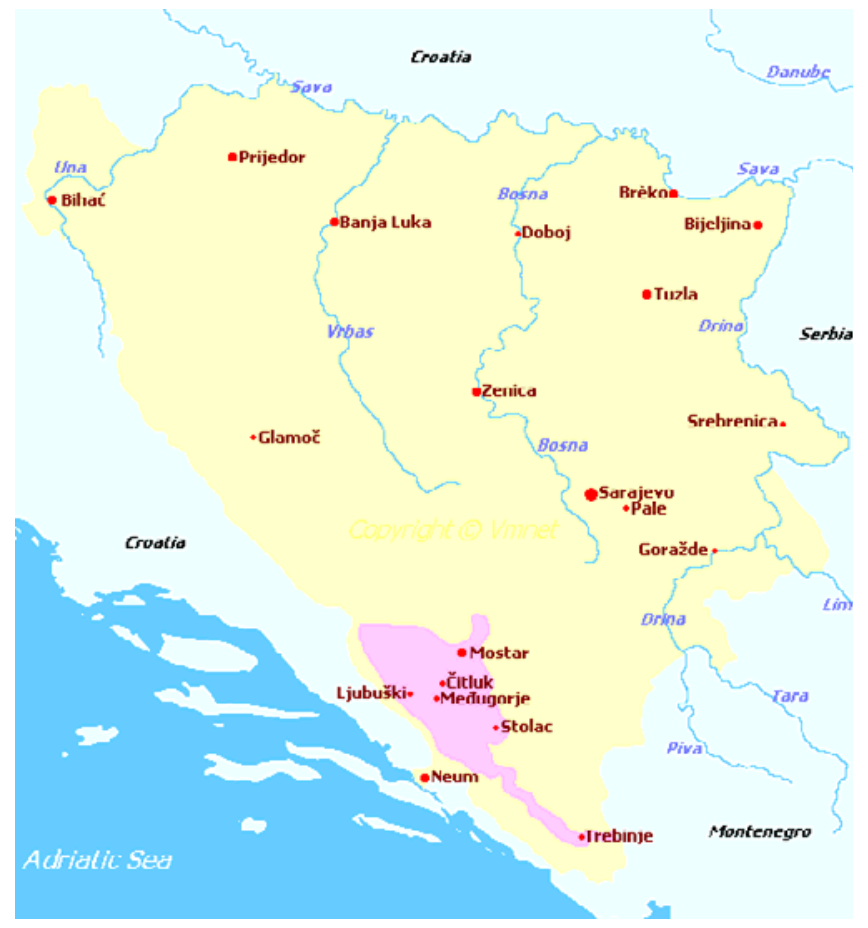

Figure 1. Map of B-H (permission of Wine and Vine Search) 
There are today 46 commercially registered wine producers and probably several hundred small producers that sell their "cuvees" along the roads. Households and farms that produce grapes for local and home production are estimated to be over 11,000 [4]. There were 3,240 hectares of wine vineyards in 2011, up 50\% from the acreage of 2005. During that same period, production increased from 5 tons per hectare to 7 tons per hectare, probably because of the planting of higher yielding varieties and possibly because of newer trellising and planting techniques. Unlike in the rest of the Balkans, local consumption of wine is low at 5.4 liters annually per person. However, this is a $170 \%$ increase over eight years earlier. Much of the wine produced, especially the lower quality wine, is exported to Serbia and Croatia. Germany takes most of the 8.5 percent that goes to EU countries (ibid). In spite of this, an analysis of B-H's wine industry by Ivankovic et al using a Policy Analysis Matrix (PAM) suggests that the net benefits

in terms of opportunity costs, while positive for domestic sales, are fewer for wine exports. The authors [5] as well as others [6] emphasize that production of quality wines and wine tourism offer increased benefits over the general export of mediocre wine that was the standard of the past industry.

What seems to be consistent about B-H's wine production is an increase in quality by most wineries. Interviews with commercial wine makers have shown that they are focusing on the marketing of traditional varieties such as Žilavka and Blatina which grow well in Herzegovinian soils, as well as other Balkan varieties like Vranac and Plavac Mali [7]. Many wineries are planting the "usual suspects"-Chardonnay, Merlot, Cabernet Sauvignon and Syrah. Many of these choices are soil dependent and may not compete as well in the market as the native specialty varietals. Regulations are still in the planning, and it is assumed that the classification of wine appellations and qualities will follow the minimum requirements of the European Union.

\section{Determining Bosnia-Herzegovina's Wine Tourism Potential: SWOT Analysis}

\subsection{Tourism in Bosnia-Herzegovina}

Bosnia-Herzegovina has recently promoted itself as a site for adventure tourism, including hiking, skiing, rafting, and spelunking [8]. (Agencies such as Sarajevo Funky Tours specialize in what might be called "extreme tourism," visiting war tunnels and the site of the genocide at Srebrenica.) The country offers incredible vistas in a very sparsely populated land. Religious tourism in the form of pilgrimage to Međugorje has been one of the major attractions for this southern region of the country. It brings on average one million visitors a year to the region.

The national tourism board Vinska Cesta Hercegovine has developed literature and an interactive site that promotes wine visitation as one of its tourism categories [9]. There is no data yet as to visitor frequency at the 29 wineries that have links on the board's website. Many of these wineries offer restaurants and at least six presently offer lodging. Unfortunately, signage and marketing seem to be lacking along the wine trails [10]. When limited hard data exists for a region, determining the present state of, and potential for, tourism can be accomplished using SWOT analysis $[11,12]$. The following looks at Strengths, Weaknesses, Opportunities and Threats for the wine tourism industry in Herzegovina (fig. 2).

\subsection{Highlights of SWOT Analysis}

As mentioned earlier, the uniqueness of the Blatina and Žilavka grape varieties is a primary strength for encouraging wine tourism in B-H. Wine connoisseurs visit particular regions of the world where the best of a particular variety is grown: the Rheingau of Germany for Riesling or Amador Foothills of California for Zinfandel. Wine tourism is strengthened by nearby tourist sites: religious, historical and adventure-related. The B-H wine region offers proximity to the Adriatic Coast, which makes it a desirable location; however, it must compete with Croatian wine regions, which are on the coast. The 
fact that Bosnia-Herzegovina is under-developed with low wages and cheap land is a double-sided sword for the country. It is the reason for the country's low per-capita income, but it also helps sales by allowing wine prices to be competitive with neighboring wealthier nations. The most important consideration to be gained from this SWOT analysis is that, with an injection of funds from international agencies and private entrepreneurs, many of the B-H wine tourism weaknesses - lack of research, poor signage, low capacity, and lack of training in the hospitality sector-could be solved. They are not endemic. However, as will be discussed in the next section, a governing mentality sometimes appears to be.

\begin{tabular}{|c|c|}
\hline $\begin{array}{l}\text { Strengths } \\
\text {--Specialty varietals Blatina and Žilavka } \\
\text {--A history of winemaking for the region } \\
\text {--Nearby religious pilgrimage site } \\
\text { Međugorje } \\
\text {--Low cost of land and labor } \\
\text {--Proximity to Mostar and other heritage } \\
\text { sites } \\
\text { along both trails } \\
\text {--Favorable agro-ecological conditions } \\
\text { for } \\
\text { growing Vitus vinifera vines } \\
\text {--Unspoiled natural vistas and outdoor } \\
\text { activities } \\
\text {--Proximity to the Croatian coast } \\
\text { (Dubrovnik in } \\
\text { particular.) }\end{array}$ & $\begin{array}{l}\text { Weaknesses } \\
\text {--Underdeveloped capacity for lodging } \\
\text { and } \\
\text { restaurants } \\
\text {--Limited research on visitors to the } \\
\text { region } \\
\text {--Long distances between some wineries } \\
\text {--Absence of integrated approach to } \\
\text { shaping } \\
\quad \text { the wine tourism industry } \\
\text {--Lack of signage } \\
\text {--Lack of expertise and training in wine } \\
\text { tourism and wine marketing } \\
\text {--Lack of coordination between wine } \\
\text { industry } \\
\text { and tourism system (clustering) } \\
\text {--Lack of outside investment resources }\end{array}$ \\
\hline $\begin{array}{l}\text { Opportunities } \\
\text {--Possible synergies between wine and } \\
\text { other } \\
\text { forms of tourism (such as religious } \\
\text { tourism) } \\
\text {--Wine tourism as a means of developing } \\
\text { regional wine branding } \\
\text {--Availability of funds for wine and } \\
\text { tourism as } \\
\text { B-H works toward joining EEC and } \\
\text { WTO } \\
\text {--Additional national funding for signage } \\
\text { and } \\
\text { road improvement } \\
\text {--Increase employment opportunities in a } \\
\text { country were unemployment is about } \\
40 \%\end{array}$ & $\begin{array}{l}\text { Threats } \\
\text {--Competition with Monte Negro and } \\
\text { Southern } \\
\text { Croatia (Dalmatia) as their tourism } \\
\text { industries } \\
\text { continue to grow } \\
\text {--Disagreement on EU standards and } \\
\text { basic } \\
\text { appellation requirements } \\
\text {--Possible incidents of sectarian violence } \\
\text { and } \\
\text { unrest } \\
\text {--Cost of low tourism turnout for three } \\
\text { months of the year (winter) } \\
\text {--Impact of tourism on a fragile } \\
\text { ecosystem }\end{array}$ \\
\hline
\end{tabular}

Figure 2. Analysis of Strengths, Weaknesses, Opportunities and Threats for B-H Wine Tourism.

\section{Discussion: The Future of Wine Tourism in Bosnia-Herzegovina}

A lengthy FAO report on the Bosnia-Herzegovina wine industry found that training in wine marketing and wine tourism is sorely needed. The organization suggests an investment of $22 \mathrm{M}$ Euros to market 
and increase wine tourism [13]. While the FAO's report is predominantly concerned with increasing wine production, one need only look at neighboring Croatia's success in wine tourism to see where the future increases in this small country's wine industry should take place. Why pay for shipping wine out of the country? Bring the drinker to the wine.

Croatia spent 29.6 million Euros (2010) on tourism, and much of that money was spent on marketing its wine regions [14]. It is difficult to determine what Bosnia-Herzegovina spends on tourism or what portion on wine tourism. Although it is a single nation, its government is divided into two independent entities, Federation of Bosnia-Herzegovina (FBiH) and Republika Srpska (RS), with parallel independent authorities for each. As Euromonitor International recently reported,

International authorities and NGOs are increasingly pushing for the greater cooperation and coordination of activities on tourism development projects, as are private investors, which see no point in financing such a complex and inefficient structure.[15]

The two wine trails of Bosnia-Herzegovina are unfortunately in different authorities.

\section{Conclusion}

This study has found that the potential for wine tourism in Bosnia-Herzegovina benefits from the region's unique ability to produce distinctive wine varieties, its scenic beauty, and - for the immediate future - the advantage of low costs and wages, which enable it to compete with more developed wine tourism in neighboring countries. Although the region faces challenges in developing wine tourism, these are overwhelmingly problems that can be solved with enough investment of time, money, knowhow and will.

Given that the war only ended two decades ago, with 800,000 refugees still displaced and onehalf million houses still not repaired for occupancy, it may be too soon to expect everything to work well. The country and the people are repairing, and wine is being produced. Hopefully, the people with influence in the government and private sectors will consider some to the suggestions outlined in the paper and wine tourism will increase in Bosnia-Herzegovina. Wine tourism has the potential of attracting international financing and sparking an integrated approach to tourism that could increase employment rates and create a new, favorable brand for the region overall.

\section{References}

1. World Bank. Bosnia and Herzegovina: from recovery to sustainable growth. Wash., D.C.: world bank country study (1997)

2. R. Hayden. "Serbian and Croatian nationalism and the wars, in Yugoslavia." Cult. Survl Quat., summer (1995)

3. Raško Vlastelica \& D. Jelić. “A building block of Herzegovina” Wine report 2013 (2013). Web site: http://www.winesofbalkans.com/index.php?index\&newsdetail=20131114-1_herzegovina-ahome-of-extraordinary-wines

4. FAO. "The wine sector in Bosnia and Herzegovina," preparation of IPARD sector analyses in Bosnia and Herzegovina, (2012)

5. M. Ivankovic‘, S`. Bojnec and A. Kolega. Competitiveness of wine production: the case of Bosnia and Herzegovina in Bodenkultur, 56 (1-4), 219-229 (2005)

6. Hall, Derek. Brand development, tourism and national identity: The re-imaging of fomer Yugoslavia, in Brand management, 9. No. 5, (1002) 121- 114 .

7. J. Hudelson, Eastern secrets: the new-old wine regions of Eastern Europe. in progress.

8. B. Tsui, Peace dividend: unspoiled hiking in the Balkans, NY Times, April 20, 2008

9. Vinska Cesta Hercegovine (2012). Web site: http://www.vinskacesta.ba/en/vinari.

10. J. Hudelson, Eastern secrets: the new-old wine regions of Eastern Europe. in progress. 
11. O. Kesar, and D. Ferjanic. Critical aspects of managing successful wine tourism development in the times of global economic crisis - a case of Croatia. 5th Interl Conference: "An enterprise odyssey: from crisis to prosperity - challenges for government and business" (2010)

12. B. Muhi, A. Katić, J. Kovačević, J. Stanković. "Development perspectives of wine tourism in Vojvodina," Tourism \& hospitality management 2010, Conference Proceedings (2010)

13. FAO. "The wine sector in Bosnia and Herzegovina," preparation of IPARD sector analyses in Bosnia and Herzegovina 95. Bosnia-Herzegovina (2012)

14. "Odluka o proglašenju državnog proračuna za 2010," Narodne novine. 2 December 2009, (2010)

15. Getz, Donald. "Life-Cycle Stages in Wine Tourism Development: A Comparison of Wine Regions in Croatia.” Tourism Rev. Intl. 13, 1, 31-49 (2009)

18. Travel and Tourism in Bosnia-Herzegovina, Euromonitor Intl. Aug 2012:1. 